\title{
In vitro culture of zygotic embryos and seeds of Caesalpinia ferrea Martius ${ }^{1}$
}

\author{
(D)Daniel da Silva ${ }^{2,5}$, Angela Maria Imakawa ${ }^{2}$, Suely de Souza Costa ${ }^{4}$ and Paulo de Tarso Barbosa Sampaio ${ }^{3,2}$
}

Received: 13.07.2018; accepted: 8.08.2018

\begin{abstract}
In vitro culture of zygotic embryos and seeds of Caesalpinia ferrea Martius). The aim of this study was to evaluate the in vitro germination of zygotic embryos and seeds of Caesalpinia ferrea Martius and the morphogenetic responses of the explants to different concentrations of growth regulators. Seeds and zygotic embryos were inoculated in MS culture medium and kept in a growth room at a temperature of $25 \pm 2{ }^{\circ} \mathrm{C}$ for 16 hours of photoperiod for 30 days. The seeds had a higher in vitro germination rate than the explants from zygotic embryos. However, zygotic embryos in MS medium supplemented with $0.9 \mathrm{mg} \mathrm{L}^{-1} \mathrm{BAP}$ had the highest percentage of regeneration (50\%), number of shoots (3.25), buds (2.85) and leaves (3.15), multiplication rate (27.75), and length of shoots $(1.96 \mathrm{~cm})$. The in vitro culture of zygotic embryos and seeds made possible the multiplication of a higher number of healthy seedlings. Thus, it can be used as an alternative technique for the propagation of this species.
\end{abstract}

Keywords: auxins, cytokinins, ironwood, morphogenesis, tissue culture

RESUMO - (Cultura in vitro de embriões zigóticos e sementes de Caesalpinia ferrea Martius). O objetivo deste trabalho foi avaliar a germinação in vitro de embriões zigóticos e sementes de Caesalpinia ferrea e as respostas morfogenéticas dos explantes em relação a diferentes concentrações de reguladores de crescimento. As sementes e os embriões zigóticos, foram inoculados em meio de cultura MS e mantidos em sala de crescimento com temperatura de $25 \pm 2{ }^{\circ} \mathrm{C}$, e $16 \mathrm{~h}$ de fotoperíodo por 30 dias. Os resultados mostraram que a taxa de germinação in vitro de sementes foi superior em relação aos explantes originados de embriões zigóticos. Entretanto, os embriões zigóticos em meio MS suplementado com 0,9 mg L-1 de BAP apresentaram a maior percentagem de regeneração $(50 \%)$, número de brotos $(3,25)$, gemas $(2,85)$ e folhas $(3,15)$, taxa de multiplicação $(27,75)$ e comprimento de brotos $(1,96 \mathrm{~cm})$. A cultura in vitro de embriões zigóticos e sementes possibilitou a multiplicação de maior número de plântulas sadias, revelando-se uma técnica alternativa para propagação desta espécie. Palavras-chave: auxinas, citocininas, pau-ferro, morfogênese, cultura de tecidos

\section{Introduction}

Caesalpinia ferrea Mart. (Brazilian ironwood, "pau-ferro" or "jucá") is a Brazilian tree species of economic potential and pharmaceutical interest due to its active principle called "Pau-ferrol", extracted from the stems of juvenile plants and used against the human topoisomerase II, which inhibits the growth of cells through the induction of apoptosis, thus becoming an important tool in the treatment of human leukemia HL60 (Nozaki et al. 2007; Ohira et al. 2013).
The propagation of $C$. ferrea is viable by seeds (Scalon et al. 2011) and by seedlings (Lima et al. 2008; Lenhard et al. 2010). In vitro propagation is a technique used in plant biotechnology that explores the totipotency of the nature of plant cells, which makes possible the reproduction of superior genotypes in vitro (Gatti et al. 2016) through small fragments of living tissue (explants) isolated from an organism and grown in a nutritious culture medium. Such advances have increased the prospects of genetic manipulation

1. Parte da Tese de Doutorado do primeiro Autor

2. Universidade do Estado do Amazonas, Escola Superior de Ciências da Saúde, Rede Bionorte, Programa de Pós-Graduação em Biodiversidade e Biotecnologia, Avenida Carvalho Leal 1777, Cachoeirinha, 69065-000 Manaus, AM, Brasil

3. Universidade do Estado do Amazonas, Escola Superior de Tecnologia, Laboratório de Cultura de Tecidos Vegetais, Av. Darcy Vargas 1200, Parque Dez de Novembro, 69065-020 Manaus, AM, Brasil

4. Instituto Nacional de Pesquisas da Amazônia, Laboratório de Propagação de Plantas, Rua da Lua s/n, Aleixo, 69060-082 Manaus, AM, Brasil

5. Corresponding author: ds.dbb@uea.edu.br 
to be used in various fields of plant biotechnology (Paiva et al. 2012). Woody species such as C. ferrea, when they are micropropagated, generally have a low rate of in vitro multiplication and rooting (Silva et al. 2018). Therefore, it is necessary to improve the propagation methods to increase the mass production of healthy and uniform plants, by multiplying selected genotypes, providing seedlings to ex situ plantations and allowing the reintroduction of plants in their natural habitat.

The zygotic embryo culture technique is based on the plant cell totipotentiality that can influence the development and regeneration of the whole plant, resulting in a rapid multiplication of plants (Liu et al. 2007). The cultivation of zygotic embryos can be used to overcome seed dormancy, caused by embryo immaturity or inhibitory substances in the endosperm, and to evaluate nutritional and physiological aspects of embryo development and seed viability, aimed to increase the knowledge of the germinative processes (George et al. 2008).

The aim of this study was to evaluate the in vitro germination of zygotic embryos and seeds of $C$. ferrea; as well as the in vitro morphogenetic response of zygotic embryos to different concentrations of 6-benzylaminopurine (BAP) and 1-naphthaleneacetic acid (NAA).

\section{Material and methods}

The experiments were carried out from March to October 2016 at the Plant Tissue Culture Laboratory (LCTV), Superior School of Technology (EST) of the University of the State of Amazonas (UEA). C. ferrea seeds were obtained from the Seed Bank of the Microbiology and Soil Fertility Laboratory of the National Institute of Amazonian Research (INPA). The seeds had a good physiological maturity and were stored at room temperature.

The MS (Murashige and Skoog 1962) culture medium was used. The $\mathrm{pH}$ of the medium was measured at 6.0 before autoclaving at $121{ }^{\circ} \mathrm{C}$ and $1 \mathrm{~atm}$ pressure for 15 minutes. The cultures were maintained in a growth room at $25 \pm 2{ }^{\circ} \mathrm{C}$ for 16 hours of photoperiod with light intensity of $52 \mu \mathrm{mol} \mathrm{m} \mathrm{m}^{-2}$ from two cold white fluorescent lamps.

Establishment and in vitro germination - Initially, the seeds were scarified on an emery stone, in the lateral region of the opposite side of the hilum to slightly wear out the tegument and thus allow the absorption of water. After scarification, the seeds were washed with neutral detergent and rinsed under running water for one minute. They were then immersed in $2.0 \%(\mathrm{v} / \mathrm{v})$ Carbendazim $^{\circledR}$ solution for 1 hour under constant stirring at $100 \mathrm{rpm}$. Afterward, the seeds were immersed in $70 \%$ alcohol for 1 minute and then in $0.25 \%(\mathrm{v} / \mathrm{v})$ sodium hypochlorite solution $(\mathrm{NaOCl})$ for 30 minutes under stirring. After disinfestation, the seeds were washed 4 times with distilled water and autoclaved. Then they were immersed in a container with distilled water sealed with polyvinyl chloride (PVC) film for 24 hours for imbibition. After this period, a horizontal incision was made at the center of the seed, separating the cotyledons using tweezers to remove the zygotic embryo, under aseptic conditions, in a laminar flow chamber.

The explants were inoculated into test tubes $(25 \times 150 \mathrm{~mm})$ containing $10 \mathrm{ml}$ of MS culture medium. After 30 days, the explants were evaluated for the percentage of germination, number of shoots, buds and leaves, length of shoots, percentage of normal plants (occurrence or not of stunted growth of the aerial part, absence of plumule and/or leaf expansion), number of roots and multiplication rate (number of shoots $\times$ number of buds) according to Santos et al. (2006).

A completely randomized experimental design, with 6 replications composed by 5 experimental units, was used for the in vitro germination. The results were subjected to analysis of variance (ANOVA) and the means were compared by the Duncan test at $5 \%$ probability.

Morphogenetic response - Seed zygotic embryos were inoculated into test flasks $(119 \times 70 \mathrm{~mm})$ containing $40 \mathrm{~mL}$ of MS culture medium supplemented with different concentrations of ANA and BAP, (totalizing) 12 treatments: T1: Control; T2: $0.9 \mathrm{mg} \mathrm{L}^{-1} \mathrm{BAP}$; T3: $1.8 \mathrm{mg} \mathrm{L}^{-1}$ BAP; T4: $3.6 \mathrm{mg} \mathrm{L}^{-1}$ BAP; T5: $0.18 \mathrm{mg} \mathrm{L}^{-1}$ NAA; T6: $0.37 \mathrm{mg} \mathrm{L}^{-1} \mathrm{NAA}+0.9 \mathrm{mg} \mathrm{L}^{-1} \mathrm{BAP}$; T7: $0.18 \mathrm{mg} \mathrm{L}^{-1} \mathrm{NAA}+1.8 \mathrm{mg} \mathrm{L}^{-1} \mathrm{BAP}$; $\mathrm{T} 8: 0.18 \mathrm{mg} \mathrm{L}^{-1}$ $\mathrm{NAA}+3.6 \mathrm{mg} \mathrm{L}^{-1} \mathrm{BAP}$; T: $0.37 \mathrm{mg} \mathrm{L}^{-1} \mathrm{NAA}$; 10 : $0.37 \mathrm{mg} \mathrm{L}^{-1} \mathrm{NAA}+0.9 \mathrm{mg} \mathrm{L}{ }^{-1} \mathrm{BAP} ; \mathrm{T} 11: 0.37 \mathrm{mg} \mathrm{L}^{-1}$ $\mathrm{NAA}+1.8 \mathrm{mg} \mathrm{L}^{-1} \mathrm{BAP}$, and T12: $0.37 \mathrm{mg} \mathrm{L}^{-1} \mathrm{NAA}$ $+3.6 \mathrm{mg} \mathrm{L}^{-1} \mathrm{BAP}$.

After 30 days of inoculation, the percentage of embryo regeneration, number of shoots and buds, multiplication rate, sprout length, number of roots and percentage of callus formation were evaluated. 
Regarding the morphogenetic response, a completely randomized experimental design in a $4 \times 3$ factorial scheme (BAP concentrations $\times$ NAA concentrations) was used, totalizing 12 treatments, with 5 replications, each one consisting of 4 experimental units. The data were subjected to ANOVA and the means were compared by the Duncan test at 5\% probability. Statistical analyses were performed using the ASSISTAT ${ }^{\circledR}$ software, version 7.7 .

\section{Results and Discussion}

The seeds started germinating between the seventh and tenth days. This result is similar to that observed by Medeiros Filho et al. (2005), who found a mean germination time of scarified $C$. ferrea seeds in greenhouse and growth room (germinator) of 7.8 and 10.5 days, respectively. There was no significant difference $(\mathrm{p}<0.05)$ between the germination rates of seeds (46.67\%) and zygotic embryos (66.67\%) (table 1). However, in vitro seed germination resulted in a higher number of shoots (1.93), buds (1.33) and roots (3.40), sprout length $(1.82 \mathrm{~cm})$, and multiplication rate of explants four times higher than the explants from zygotic embryos of $C$. ferrea (table 1).

The formation rate of normal seedlings (figure 1) from the in vitro germination of zygotic embryos $(13.33 \%)$ and seeds $(20 \%)$ was low in comparison to the growth of the seedlings. These differences can be attributed to losses due to microbial contamination and to the latency in the development of seedlings cultured in vitro, which resulted in the absence of leaf expansion and in the germination of explants. This fact is possibly related to the high osmotic pressure reducing plant growth and affecting the cell metabolism, acting as a barrier to leaf expansion (Pinheiro \& Chaves 2011).

Regarding the hypothesis, it is expected to obtain a high number of shoots of zygotic embryos cultured in vitro, due to the high totipotency of these explants (Bhojwani \& Dantu 2013). The lowest number of shoots and buds occurred in the zygotic embryos, which is possibly related to shoots of fasciculate apex and lower internode elongation (figure 1a), differing from the seedlings originated by seed germination, which showed a higher internode elongation and uniformity (figure 1b). This result makes it possible to establish the in vitro culture of $C$. ferrea, considering that from a seedling which can produce 10 nodal segments.
The lower multiplication rate of seedlings originated from zygotic embryos, in comparison to the seeds, suggests the need to carry out new studies on the morphogenetic response of the zygotic embryos regeneration, considering the fact that zygotic embryos are explants with tissue of high totipotency (Kumar \& Reddy 2011).

The effect of hormone concentrations as a morphogenetic response resulted in significant differences $(\mathrm{p}<0.05)$ when $C$. ferrea explants were subjected to isolated concentrations of BAP (figure 3a). The concentration of $0.9 \mathrm{mg} \mathrm{L}^{-1} \mathrm{BAP}$ (T2) in the MS medium stimulated the highest percentage of regeneration (50\%), number of shoots (3.25), buds (2.85) and leaves (3.15), multiplication rate (27.75) and shoots length (1.96) per explant (figures 2a, 2b, $2 \mathrm{c}, 2 \mathrm{~d}, 2 \mathrm{e}$ and $2 \mathrm{f}$ ).

The interaction between NAA and BAP influenced the oxidation of explants, and the highest concentrations significantly reduced the induction of shoots (figure 2b). Excessive concentrations of cytokinins and auxins when applied to the sprout induction medium may compromise sprouting from the embryonic axes, affecting the growth of the explants, in addition to being a reduction factor of the multiplication rate (Wójcikowska \& Gaj 2017).

In tissue culture, growth regulators and hormones act at low concentrations in plant growth and development (Cid \& Teixeira 2014). This fact was observed in explants of $C$. ferrea treated with the lowest concentration of BAP, which stimulated the highest regeneration rate of zygotic embryos (figures $2 \mathrm{a}$ and $3 \mathrm{~b}$ ) and shoots (figures $2 \mathrm{~b}$ and $3 \mathrm{c}$ ). Similar results were observed by Fonseca et al. (2014) who verified the highest regeneration rate of zygotic embryos of Erythrina velutina Willd. (Leguminosae) when they were cultured in vitro in MS medium supplemented with $4 \mu \mathrm{M}$ BAP.

Regarding the development of zygotic embryos, there was a reduction in the number of buds when the explants were subjected to isolated concentrations of NAA, or to combinations of NAA with BAP (figure 2c). The reduction in the number of buds may be related to the high concentrations of auxin/ cytokinin which inhibited the development of the lateral and adventitious buds in the $C$. ferrea explants. Cytokinins are responsible for cell division, apical dormancy overcoming, and induction of axillary bud proliferation in explants cultured in vitro (Miransari \& Smith 2014). 
Table 1. Percentage of germination (GER) and normal plantlets (NP), number of shoots (NS), number of buds (NB) and number of leaves (NF), shoot length (SL), number of roots (NR) and rate of multiplication (RM) obtained from zygotic embryos and Caesalpinia ferrea seeds after 30 days of inoculation in MS culture medium.

\begin{tabular}{lcccccccc}
\hline \multirow{2}{*}{ Explants } & \multicolumn{7}{c}{ Variables } \\
\cline { 2 - 9 } & GER (\%) & NS (\%) & NS & NB & NF & BL $(\mathrm{cm})$ & NR & RM \\
\hline Zygotic embryos & $66,67 \mathrm{a}$ & $13,33 \mathrm{a}$ & $0,83 \mathrm{~b}$ & $0,40 \mathrm{~b}$ & $1,70 \mathrm{a}$ & $0,52 \mathrm{~b}$ & $0,76 \mathrm{~b}$ & $0,50 \mathrm{~b}$ \\
Seeds & $46,67 \mathrm{a}$ & $20,0 \mathrm{a}$ & $1,93 \mathrm{a}$ & $1,33 \mathrm{a}$ & $3,40 \mathrm{a}$ & $1,82 \mathrm{a}$ & $4,03 \mathrm{a}$ & $2,50 \mathrm{a}$ \\
\hline
\end{tabular}

Means followed by the same letter do not differ statistically among themselves the Duncan's test $(p<0.05)$

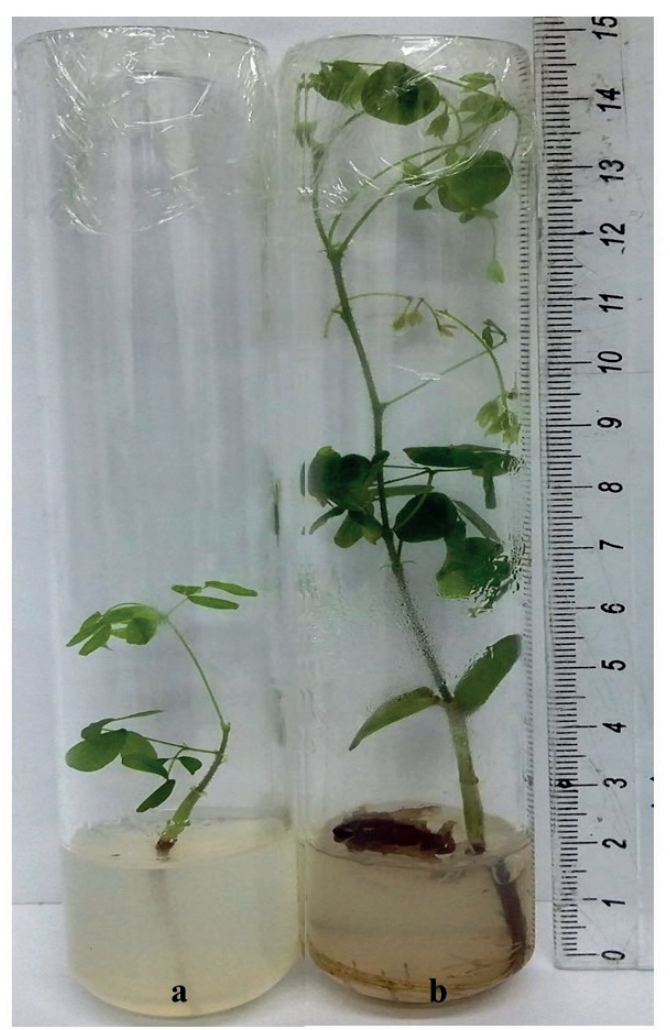

Figure 1. In vitro culture of germinated seedlings from zygotic embryos (a) and seeds (b) of Caesalpinia ferrea in MS medium after 30 days.

The multiplication rate (figure 2e) of the zygotic embryos was higher (27.75) than that observed by Silva et al. (2018) who studied explants of nodal segments and axillary buds of the species (10.06). The shoots from zygotic embryo cultured only at the $0.9 \mathrm{mg} \mathrm{L}^{-1}$ BAP concentration had a mean length of $1.96 \mathrm{~cm}$ (figure $2 \mathrm{f}$ and $3 \mathrm{~d}$ ). It was also observed that the highest concentrations of BAP and NAA resulted in the lowest sprout growth (figure 2f). Miao et al. (2016) report that the ability of tissues to respond to the growth and development of shoots depends on various endogenous and/or exogenous factors and their interactions.
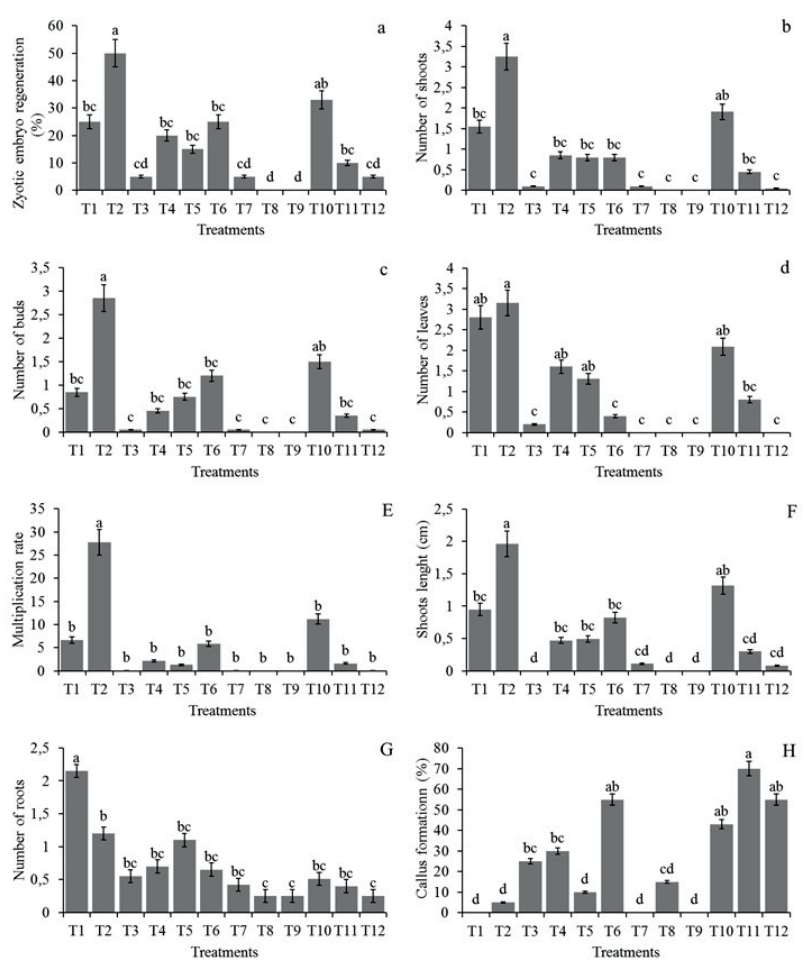

Figure 2. Percentage of regeneration (a), number of shoots (b), buds (c) and leaves (d), multiplication rate (e), shoot length (f), number of roots $(\mathrm{g})$ and callus formation $(\mathrm{h})$ obtained from zygotic embryos of Caesalpinia ferrea after 30 days of culture in vitro in MS medium supplemented with different concentrations of BAP and NAA. Means followed by the same letter do not differ statistically among themselves by the Duncan's test $(p<0.05)$.

Root formation was observed in all treatments; however, the culture medium with no growth regulators (T1) had the highest mean ( 2.15 roots/explant), significantly differing from the other combinations of auxin and cytokinin (figure $2 \mathrm{~g}$ ). Natural or synthetic auxins generally fail to stimulate root formation in vitro. Souza \& Pereira (2007) report that certain plant species, especially woody plants, are difficult to root in the presence of auxins, indicating that other factors may influence the in vitro rooting. 


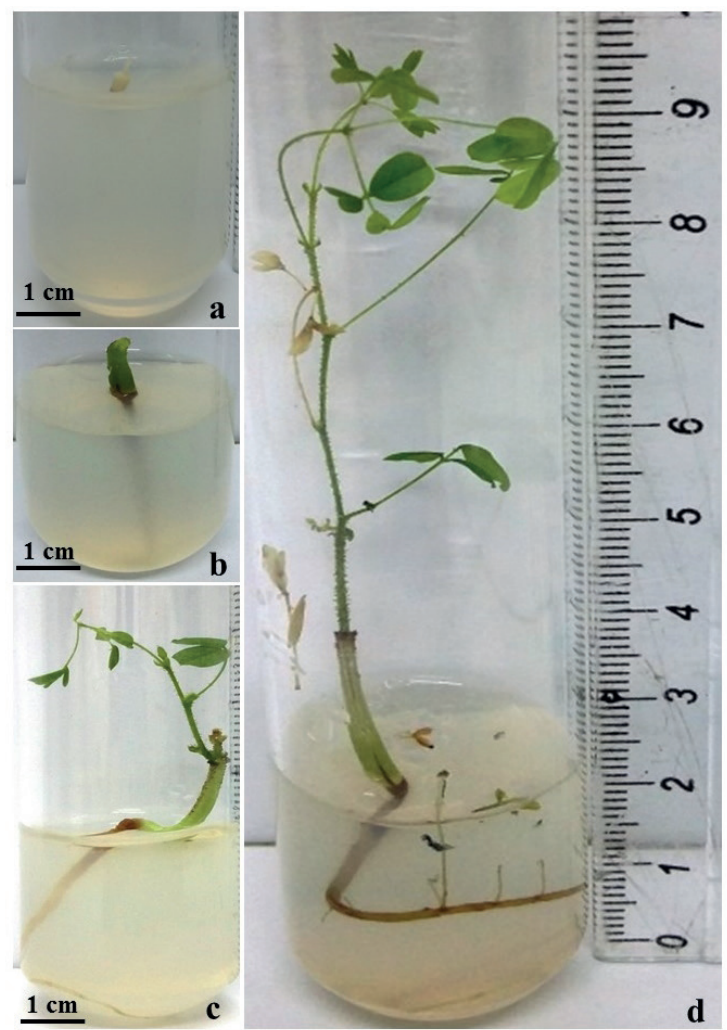

Figure 3. Developmental phases of zygotic embryo and seedling formation of Caesalpinia ferrea in MS medium supplemented with $0.9 \mathrm{mg} \mathrm{L}^{-1}$ BAP: Initial culture of zygotic embryo (a); Germination of zygotic embryo at 10 days (b); Seedling with shoots, buds and primary root at 20 days (c); Normal seedling after 30 days of in vitro culture (d).

The different combinations between BAP and NAA significantly reduced root induction (figure $2 \mathrm{~g}$ ). Cytokinins added to the culture medium generally promote the formation of adventitious shoots; whereas auxins stimulate the formation of the root system in tissues predisposed to rooting (Jardim et al. 2010). $C$. ferrea explants, when subjected to isolated concentrations of NAA, had a low rooting rate (figure $2 \mathrm{~g}$ ).

With regards to the callus formation, the interaction between NAA and BAP resulted in significant differences (figure $2 \mathrm{~h}$ ). The combination of $0.37 \mathrm{mg} \mathrm{L}^{-1} \mathrm{NAA}$ with $1.8 \mathrm{mg} \mathrm{L}^{-1}$ BAP (T11) promoted a higher percentage of brown and compact callus formation (70\%), followed by $0.18 \mathrm{mg} \mathrm{L}^{-1} \mathrm{NAA}$ and $0.9 \mathrm{mg} \mathrm{L}^{-1} \mathrm{BAP}$ (T6) and $0.37 \mathrm{mg} \mathrm{L}^{-1} \mathrm{NAA}$ and $3.6 \mathrm{mg} \mathrm{L}^{-1}$ BAP (T12), both with $55 \%$, and $0.37 \mathrm{mg}$ $\mathrm{L}^{-1} \mathrm{NAA}$ and $0.9 \mathrm{mg} \mathrm{L}^{-1}$ BAP (T10) with $40 \%$.

Cells or tissues can usually differentiate due to morphogenetic responses to different growth regulators (Elhiti et al. 2013) (figure 2h). The seedlings obtained in this study showed a normal phenotype, but there were cases of changes in leaf morphology and seedling stem, which was broader and with frequent callus production at the base. Almeida et al. (2001) report that these somaclonal variations occur in plants regenerated from callus obtained from epicotyl explants and cotyledonary leaves, where higher rates of somaclonal variation are found.

\section{Conclusions}

The highest rates of regeneration and multiplication of $C$. ferrea zygotic embryos were obtained in MS culture medium supplemented with $0.9 \mathrm{mg} \mathrm{L}^{-1}$ BAP. The highest mean (2.15) of roots/ explants was observed in the absence of a growth regulator, benefiting the survival of the seedlings. The results pointed out the importance of evaluating the mineral composition of the culture medium and growth regulators in order to determine optimal conditions for the propagation of $C$. ferrea from seeds and zygotic embryos for commercial purposes as well as for conservation and multiplication in vitro of this species.

\section{Acknowledgments}

The authors thank the Foundation for Research Support of the Amazonas State (FAPEAM) for granting scholarship to the first author by the Postgraduate Program in Biodiversity and Biotechnology of the University of the state of Amazonas (Bionorte/UEA). They also thank Dr. Luiz Augusto Gomes de Souza of the National Institute of Amazonian Research (INPA) for the identification and supply of $C$. ferrea seeds.

\section{Literature cited}

Almeida, L.P., Oliveira, R.P. \& Dantas, J.L.L. 2001. Indução e desenvolvimento de calos e embriões somáticos em mamoeiro. Scientia Agricola 58:51-54.

Ali, M., Isah, T. \& Mujib, A. 2016. Climber Plants: medicinal importance and conservation trategies. In: A. Shahzad, S. Sharma \& A.S. Saeed (eds.). Biotechnological strategies for the conservation of medicinal and ornamental climbers. Springer, Cham, pp. 101-138.

Bhojwani, S.S. \& Dantu, P.K. 2013. Zygotic embryo culture. In: Plant tissue culture: an introductory text. Springer, India, pp. 127-140.

Cid, L.P.B. \& Teixeira, J.B. 2014. Explante, meio nutritivo, luz e temperatura. In: L.P.B. Cid (ed.). Cultivo in vitro de plantas,Embrapa, Brasília, pp.17-52. 
Elhiti, M., Stasolla, C. \& Wang, A. 2013. Molecular regulation of plant somatic embryogenesis. In Vitro Cell Developmental Biology - Plant 49: 631-642.

Fonseca, P.T, Nepomuceno, C.F., Alvim, B.F.M. \& Santana, J.R.F. 2014. Resposta morfogênica de embriões zigóticos de Erythrina velutina Willd: (Leguminosae) cultivados in vitro. Revista Ceres 61: 605-611.

Gatti, I., Guindón, F., Bermejo, C., Espósito, A. \& Cointry, E. 2016. In vitro tissue culture in breeding programs of leguminous pulses: use and current status. Plant Cell, Tissue Organ Culture127: 543-559.

George, E.F., Hall, M.A. \& Klerk, G.J. 2008. Plant Tissue Culture Procedure - Background. In: E.F. George, Hal, M.A \& G-J De. Klerk (eds.). Plant Propagation by Tissue Culture, Springer, Dordrecht, pp. 1-28.

Jardim, L,S., Sampaio, P.T.B., Costa, S.S., Gonçalves, C.Q.B. \& Brandão, H.L.M. 2010. Efeito de diferentes reguladores de crescimento na regeneração in vitro de pau-rosa (Aniba rosaeodora Ducke). Acta Amazonica 275: 275-280.

Kumar, N. \& Reddy \& M.P. 2011. In vitro plant propagation: a review. Forest Science 27: 61-72.

Lenhard, N.R., Scalon, S.P.Q. \& Novelino, J.O. 2010. Crescimento inicial de mudas de pau ferro (Caesalpinia ferrea Mart. ex Tul. Var. leiostachya Benth.) sob diferentes regimes hídricos. Ciencia e Agrotecnologia 34: 870-877.

Lima, J.D., Silva, B.M.D.S.E., Moraes, W.D.S., Dantas, V.A.V. \& Almeida, C.C. 2008. Efeitos da luminosidade no crescimento de mudas de Caesalpinia ferrea Mart. ex Tul. (Leguminosae, Caesalpinoideae). Acta Amazônica 38: 5-10.

Liu, W., Chen, X., Liu, G., Liang, Q., HE, T. \& Feng, J. 2007. Interspecific hybridization of Prunus persica with $P$. armeniaca and $P$. salicina using embryo rescue. Plant Cell Tissue Organ Culture 88: 289-299.

Medeiros Filho, S., Silva, M. A. P. \& Santos Filha, M. E. C. 2005. Germinação de sementes e desenvolvimento de plântulas de Caesalpinia ferrea Mart. ex Tul var. ferrea em casa de vegetação e germinador. Revista Ciência Agronômica 36: 203-208.

Miao, Y., Zhu, Z., Guo, Q., Yang, X., Liu, L., Sun, Y. \& Wang, C. 2016. Dynamic changes in carbohydrate metabolism and endogenous hormones during Tulipa edulis stolon development into a new bulb. Journal Plant Biology 59: 121-132.
Miransari, M. \& Smith, D.L. 2014. Plant hormones and seed germination. Environmental and Experimetal Botany 99: 110-121.

Murashige, T. \& Skoog, F. 1962. A revised Medium for rapid growth and bio assays with Tobacco tissue cultures. Physiology Plant 15: 473-497.

Nozaki, H., Hayashi, K.I., Kido, M., Kakumoto, K., Ikeda, S., Matsuura, N., Tani, H., Takaoka, D., Iinuma, M. \& Akao, Y. 2007. Pauferrol A, a novel chalcone trimer with a cyclobutane ring from Caesalpinia ferrea mart exhibiting DNA topoisomerase II inhibition and apoptosis-inducing activity. Tetrahedron Letter 48: 8290-8292.

Ohira, S., Takaya, K., Mitsui, T., Kido, M., Kakumoto, K., Hayashi, K.I., Kuboki, A., Tani, H., Ikeda, S., Iinuma, M., Akao, Y. \& Nozaki, H. 2013. New chalcone dimers from Caesalpinia ferrea Mart act as potent inhibitors of DNA topoisomerase II. Tetrahedron Letter 54: 5052-5055.

Pinheiro, C. \& Chaves, M.M. 2011. Photosynthesis and drought: can we make metabolic connections from available data?. Journal Experimetal Botany 62: 869-882.

Santos, R.B., Paiva, R., Nogueira., Oliveira, L.M., Silva, D.P.C., Martinotto, C., Soares, F.P. \& Paiva, P.D.O. 2006. Micropropagação de pequizeiro (Caryocar brasiliense Camb). Revista Brasileira de Fruticultura 8: 293-296.

Paiva, R., Silva., D.P.C. \& Silva, L.C. 2012. Micropropagação e conservação in vitro de plantas. In: J.C. Silva \& A.A.S. Silva (eds.). Sustentabilidade produtiva do cerrado. Composer, Uberlândia, pp. 22-33.

Scalon, S. P.Q., Teodósio, T.K.C. \& Novelino, J.O. 2011. Germinação e crescimento de Caesalpinia ferrea Mart. ex Tull. em diferentes substratos. Revista Árvore 35: 633-639.

Silva, D., Imakawa, A.M., Bruno, F.M.S., Costa, S.S. \& Sampaio, P.T.B. 2018. In vitro propagation and seedling acclimatization of Caesalpinia ferrea Mart., a valuable medicinal plant in the Amazon (Fabaceae). Boletim do Museu Paraense Emílio Goeldi. Ciências Naturais 13: 57-65.

Souza, A.V. \& Pereira, A.M.S. 2007. Enraizameto de plantas cultivadas in vitro. Revista Brasileira de Plantas Medicinais 9: 103-116.

Wójcikowska, B. \& Gaj, M.D. 2017. Expression profiling of auxin response factor genes during somatic embryogenesis induction in Arabidopsis. Plant Cell Reports 36: 843-858. 